\title{
The Influence of Eastern and Western Architectural Models on the Churches Built in the Province Macedonia in the 5th- $6^{\text {th }}$ C.
}

\author{
Snežana Filipova \\ University of St. Cyril and Methodius \\ Faculty of Philosophy, Institute of Art History and Archaeology
}

Doi:10.5901/ajis.2013.v2n3p425

\begin{abstract}
Most of the basilicas built in the 5-6th C. on the territory of today's Republic of Macedonia that numbers over 400 are three nave and have central semicircular altar apse. Yet, there are models that show direct influences from Constantinople, Palestine and likely Italy. The political and church events in the 5th C. especially related to the bishop of Milan, and the 6th C. event related to the vicar of Thessalonica seem to have large impact on the models of the erected churches. Some scholars mention the influence of the architecture from Dacia Mediterania, but the very little number of churches erected there and the way the Christianity have been spread shows other picture, that Krautheimer have pointed in his research decades ago. The rare examples of polygonal apse churches and churches with flat apses from outside, together with the very unusual church from the vicinity of Stip with elaborated plan that imitates an important Palestine church,speak of Eastern architecture popularity and following of modern and rare models that were used for martyria and important church commemorative buildings on the East in the first centuries of Christianity. Rotundas-martyria from Konjuh and Krupiste, ambulatories and crypts that were approached from the outer side of the altar apse are part of the very rich vocabulary of the local architects and testify of the good taste and modern approach to church architectural solutions of the founders.
\end{abstract}

\section{Introduction}

Church design in the Middle Ages was an ongoing evolutionary process. In the 4-5th $\mathrm{C}$ large influence in art came from the East, where the oriental traditions have long time ago merged with the Hellenistic one's. The forms and format of early Christian worship were greatly influenced by those found in the Jewish synagogues, even the architecture (raised platforms and pulpits at the front, rows of benches or pews facing the front of the auditorium etc.). The paintings of the first domus ecclesiae also show large similarities with those applied in the synagogues, as the neighboring synagogue and the domus ecclesiae in Dura Europos proves. ${ }^{1}$

There are over four hundred Early Christian churches on the territory of the present-day Republic of Macedonia. Like within Byzantium, most of the church plans in the province Macedonia are basilical $(85 \%)^{2}$, and their liturgical stone furniture and mosaics are dated mostly in the $2 / 2$ of the $5^{\text {th }} \mathrm{C}$, when the figural themes are born again. In the $6^{\text {th }} \mathrm{C}$. there is an expansion of the architectural and mosaic art due to demographical and economical development of Byzantium.

\section{Research Methods}

Archaeological research, conclusions made by their published results as stylistic art history method, comparative method, and history of architecture and architectural iconography

Archaeological research shows uninterrupted life in Christian Antiquity, especially in the Episcopal centers in Pelagonia, along Bregalnica and Struma and it seems even where strong earthquake devastated the region of Scupi (the capital of Dardania, today's' Skopje), life and building continued as seen by the employment of three sided central apse

\footnotetext{
${ }^{1}$ F. Snyder, Ante pacem: archaeological evidence of church life before Constantine, pp. 129-134, Mercer University Press, 2003, L. Teicher, "Ancient Eucharistic Prayers in Hebrew (Dura-Europos Parchment D. Pg. 25)", The Jewish Quarterly Review New Series 54.2 (October 1963), pp. 99-109.

2 Marina Oncevska, The Big Early Christian Basilica in Scupi and Early Christianity, MN 34-35, 97-112, fnote 32.
} 
and two lateral ones that is characteristic for the period of Justinian I. ${ }^{3}$ The political and church events in the 5th C. especially related to the bishop of Milan, and the 6th $\mathrm{C}$. event related to the vicar of Thessalonica seem to have large impact on the models of the erected churches. ${ }^{4}$

For the history of Macedonian early Christian architecture of great importance are several preserved architectural plans inscribed on a stone or ceramic from Lychnidos 5 and one from Sushica near Skopje ${ }^{6}$.

From the period of Justinian I come a lot of basilicas, and the mid of the century and the $2 / 2$ brings three apsidal basilicas instead of single apse one. The concentration of the basilicas is around and within the large cities and bishoprics. ${ }^{7}$ Basilica with dome appears in the $6^{\text {th }} \mathrm{C}$. and expansion of central plan churches with domes follows.

The small city church in Bargala is one of the pseudo basilicas with shortened naos (its length is almost the same with the width 6,2:5,7 m.), where four entrances were discovered, one from the west, two from the east and one from the south. This type of naos is very rare in the Balkans and examples come from Bulgaria (Melnik, St. Nicholas, Episcopal basilica, Sandanski, the old Metropolia in Neseber, the basilica in Sliven). ${ }^{8}$

There is combination of rotunda inscribed within trapezoid (Konjuh), rotunda (Krupishte), and small free standing cross shaped churches, invented in Syria and Palestine according to some researchers, and typical in the time of Justinian.

Over 60 basilicas are either excavated or recognized within the Episcopal cities, and 250 outside them, 15 within fortresses. Their apses are mostly half circular, rarely three sided or rectangular, and once only flat from the outer side and half circular from the inner side $\left(\operatorname{Drenov} 0^{9}\right)$. Their atriums are positioned on the west, except the southern basilica at Plaosnik (added on the north). There are less examples of churches with rectangular or trapezoid-three sided central apse but their number is not to be neglected (Konjuh, Tudence, Heraclea, Scupi, Strumica, Morodviz, Crkviste Zelenikovo, near Skopje, Manastir Gradot near Prilep, Golem Grad Prespa-2 or 3 churches $^{10}$, etc.). It is the shape of the central altar apse of St. Sophia in Constantinople built over the Constantine basilica in the $6^{\text {th }} \mathrm{C}$. Almost all of the apses of the basilicas in Caricin Grad and its surrounding are three sided. This was seen as the influence coming from the northDacia Mediterranea to the south (Macedonia) according to Snively, but it look like is the other way round. "The tri-apsidal churches are more frequent in absolute and relative numbers in Palestine than in the adjacent Holy Land Provinces and in the other Provinces of the Byzantine Empire. An indication, that Palestine served as the centre for the Cult of the Saints and Martyrs in the Roman and Byzantine Periods and was the nucleus for construction of the tri-apsidal basilicas."11

Coming from Palestine through Constantinople this model of church apse has been accepted in the province of Macedonia already in the $5^{\text {th }} \mathrm{C}$. (Morodvis, one nave church, Golem grad, Prespa) and later mostly in the mid $6^{\text {th }} \mathrm{C}$. reaches the north (Caricin Grad, Romuliana) or is result of the Justinian's building activity. Macedonian' several hundreds of basilicas have no transept as the large basilicas in Caricin Grad or Greece have.

Stence Polog church is enigmatic, it has 3 baptisteries within the same church. ${ }^{12}$ The large basilica from Konjuh has employed two ambos, small ambo within the presbyterium and a larger one in the unusual location at the south side of the nave which is the case only with the Octogon church and the Museum basilica in Philippi. Yet, I think here we shall consider using the term lectern for the smaller one and pulpit, or pulpits for the larger one. The first was used for reading the Epistle, and the other the larger one for reading the Gospel. ${ }^{13}$

\footnotetext{
${ }^{3}$ Caroline Snively, The new basilica at Golemo Gradište, Konjuh: a 6th C. church in the province of Dardania) Nish and Byzantium IX, 187-201198.

${ }^{4}$ Rajko Bratoz, Rajko Bratoz, The Early Christian Church in Macedonia and its relation to Rome, MH 13, 3-82.

${ }^{5}$ Vera Bitrakova, Starohristijanski spomenici vo ohridsko, Ohrid 1975, 197.

${ }^{6}$ Snežana Filipova, Early Christian Cultural Centres, Patrimonium 7/8, 2010, T 1, fig. 13, 18.

7 Snežana Filipova, Early Christian Cultural Centres in Republic of Macedonia along the Via Egnatia, Patrimonium 7-8, 2010, 127-148, 134.

8 Trajche Nacev, Julij Frkov, Archaeological architectonic research and reconstruction of an urban early Christian basilica in the city of Bargala, MH 34-35, 157-172,

9 V. Georgieva, V. Lilčić, K. Filipova, The early Christian basilica at Drenovo, MH 34-35, 67-76.

10 Bitrakova, Golem Grad Prespa I, Skopje 2011.

${ }^{11}$ Shlomo Margalit, The bi-apsidal churches in Palestine, Jordan, Syria, Lebanon and Cyprus. http://www.christusrex.org/www1/ofm/sbf /Books/LA40/LA40321Margalit_Bi-apsidal.pdf

12 Velimir Cvetanovski, Gradot Stenče, MH 29, 2006, 31-46, 39.

13 "In many Christian churches, there are two speakers' stands at the front of the church. Often, the one on the left (as viewed by the congregation) is called the pulpit. Since the Gospel lesson is often read from the pulpit, the pulpit side of the church is sometimes called
} 
Bitrakova, speaking of the three-side apses of the churches on the Prespa lake island Golem Grad, wrongly concludes that they are rarely used type preferred mostly in the $5-6^{\text {th }} \mathrm{C}$. in Constantinople ${ }^{14}$. Snively considers this type of apse as characteristic for the time of Justinian and that is why she thinks the new big basilica in Scupi that has such polygonal apse has not been necessarily erected before the earthquake in 518 .

As it has been recently concluded by S. Margalit, by the enormous number of examples it is Palestine where we shall look for the origin of this kind of polygonal apses.

Closest parallels for the tetraconchal church in Lychnidos, at Plaosnik or the double shell type of churches, come from Syria's cathedrals or mausoleums: cathedral church and martyrium at Resafah, early $6^{\text {th }} \mathrm{C}$, in Apameia, Kalat al Mudik, late $5^{\text {th }} / 6^{\text {th }} \mathrm{C}$., as well as Balkan area: the church over the Hadrian's stoa in Athens, Perustica Red Church, the church in Adrianopolis, Holy Virgin church in Amida, Diarbekir in Turkey etc. This type of churches were built in the capitals of the Eastern provinces. ${ }^{15}$

There are only a few examples of elongated altar apses added to the basilica or other type of churches but often the presbitery has relatively short space on the eastern side of the naos and the altar cancel with one segment enters into the space of the altar apse. Sintronos with one or more stairs is often incorporated within the altar apse, while side sintroni are rare. Churches with wider naos then length prevail in Macedonia, in Dacia Mediterranea three-nave basilicas have width almost as length.

Most of the large or Episcopal basilicas, but also smaller provincial one-nave churches have tribelon entrance to the nave (Bargala, Scupi, etc.). Usually the baptisteries attached to the churches are positioned to the south. Exception is the so called Northern basilica in Stobi where the baptistery is on the north side (like. The $4^{\text {th }} \mathrm{C}$. churches from Stobi (the old Episcopal basilica), Ohrid and their vicinity, have modest inner decoration, but already in the $5^{\text {th }} \mathrm{C}$. get rich and prestigious outlook. ${ }^{16}$

The plans of the basilical and central type of churches show Constantinopolitan and Syrian influences, the Constantinopolitan influence dominates, along with the Syrian and Palestine features that have been incorporated, especially when mosaic art (Lychnidos), ambo's (Konjuh), and polygonal three-sided central apses or Church of Nativity in Bethlehem model are concerned. This was characteristic mostly of the time of Justinian, when central sacral building of three-foil (built under the Old St. Clement and St. Naum ${ }^{17}$ ), tetra-conchal and rotunda plan were erected everywhere within the Empire..$^{18}$ The $11^{\text {th }} \mathrm{C}$. church of holy Virgin in Veljusa is also tetra-conch inscribed in a square, and might have been inspired by earlier building, since there are a lot of architectural sculpture and parapet slabs discovered dispersed around the Medieval church.

The iconography and style of the ambo found in the rotunda in Konjuh shows influences from the $6^{\text {th }} \mathrm{C}$. art of

the gospel side. The other speaker's stand, usually on the right (as viewed by the congregation), is known as the lectern. Because the epistle lesson is usually read from the lectern, the lectern side of the church is sometimes called the epistle side. In churches where there is only one speaker's stand in the center of the front of the church, it serves the functions of both lectern and pulpit and is properly called the ambon or ambo. It was originally an elaborate raised platform in the middle of the nave from which the Epistle and Gospel would be read, and was occasionally used as a speaker's platform for homilies. It was joined to the sanctuary by a raised walkway called the soleas." http://www.shadysidelantern.com/if_pulpits_could_talk.htm See also In many ancient churches it was common to have two ambos - large elevated stone podiums placed opposite each other on either side of the nave - before entering the sanctuary. The one on the right was taller and more richly decorated and was reserved for the proclamation of the Gospel and occasionally substituted the cathedra as the place of episcopal preaching. The left-side ambo was divided into two levels, the higher for reading the Epistle and the lower for the chanter of the responsories." http://www.ewtn.com/library/liturgy/zlitur246.htm

14 Vera Bitrakova, Golem Grad Prespa I, Skopje 2011, 87.

${ }^{15}$ Nadja Kurtović Folis, Renata Milić, Niš and Byzantium IX, Late Antique centrally planned buildings and their influence on renaissance architecture, 267-282. M.Mundell Mango, Building and architecture, in: The Cambridge Ancient History, vol. XIV, Cambridge 2000, 958961.

${ }^{16}$ Aleksova, Lilcic, The Early Christian Churches in Macedonia, MH 5, 1997, 15.

${ }_{17}$ We know that when arriving in Ohrid in 983 St. Clement choose the existing three-foil building, probably earlier martyrium (was it built in the 7th C.? and who would have built it at those times of uncertainty, as some scholars think) as a centre for his missionary work and soon he enlarged it on its west side. The old structure obtained a liturgical function of an altar. See Katerina Hristova, Late Medieval Coin Finds from St. Clement's Church of St. Panteleimon in Ohrid, Folia Archaeologica Balkanika I, 2006, 485-502, 485, footnote 1. The 11th C. church of holy Virgin in Veljusa is also tetra-conch inscribed in a square, and might have been inspired by earlier building, since there are a lot of architectural sculpture and parapet slabs discovered disperse around the Medieval church.

${ }^{18}$ Filipova, Early Christian Cultural Centres, 134. The 11th C. church of holy Virgin in Veljusa is also tetra-conch inscribed in a square, and might have been inspired by earlier building, since there are a lot of architectural sculpture and parapet slabs discovered disperse around the Medieval church. See Petar Miljkovic Pepek, Veljusa, Skopje 1981. 
Ravenna (according to I. Mikulcic), while S. Radojcic thought of oriental influences. ${ }^{19}$ ), and that is actually Constantinopolitan art, employed in the city that became the seat of the Western Empire since the early $5^{\text {th }} \mathrm{C}$. and later on the Exarchate of Ravenna was a centre of Byzantine power in Italy.

The corridor ambulatory or kyklion in the apse is also rather specific feature for the region of the provinces of Macedonia, and is to be found in the rotunda in Konjuh, where there was staircase in the middle, at the large Konjuh basilica, and the Episcopal basilica in Stobi ${ }^{20}$, Episcopal basilica, Thessalonica ${ }^{21}$, and Epirus-Basilica B, Nikopolis). It served for the believers to look at the relics in the crypt not interrupting the mass.

Also the Basilica II from Davina Kula, v. Cucer, Skopje apart from the main entrance at the usual western side, shows two entrances in the lateral pastoforia of the altar from the outer eastern wall. ${ }^{22} \mathrm{~A}$ variation of this shows the small church from Konjsko, Golem Grad, where there are two entrances to this lateral rooms-annexes on the south and north of the single round apse, from their eastern side and no other entrance or connection with the naos or altar. The one nave cemeterial church at Konjusnica, Orman, near Skopje has only one northern entrance to these annexes flanking the main altar apse, while the western annexes on the south and north of the narthex have apsidal endings. ${ }^{23}$

Churches with lateral square rooms flanking the central altar rounded apse, and with annexes to the narthex (or were these rooms actually diaconikon and prothesis?) at v. Orman, near Skopje have entrance to the nave from the north mid side of the single nave. ${ }^{24} \mathrm{Adj}$ joined multiple rooms -annexes to the northwest or southwest of the narthex are seen rarely in the province of Macedonia-Episcopal basilica Stobi, small one nave churches in the region of Prilep, at the Episcopal basilica and Cemetery Basilica at Dion, Museum basilica at Philippi, basilicas A, B,D,E at Amphipolis, Sveti Erazmo, Ohrid, Arapaj and Nikopolis B in the province of Epirys.

The atrium becomes frequent in the churches of the larger cities in provinces Macedonia I and II. (Snively, op.cit. Niš and Byzantium III, 2005, 219.). It appears in the $4^{\text {th }} \mathrm{C}$. in the Eastern province Palestine, as well as in Constantinople and Rome, and in the time of Justinian has been added to the older churches that did not have one. ${ }^{25}$

In 2005 at the site Kula, v. Kalauzlija Štip one nave church with large apse have been discovered (13,80X8.75 m., inner space 11,30X6,25 m, walls are 1,25 $\mathrm{m}$ wide). The site is known also as the old Kozjak (name of the village where the Episcopal see Bargala is situated). Three graves were incorporated within the outer pilasters and church walls, one of the tomb is painted with crosses inscribed in a circles and its position is between the southern wall pilasters. ${ }^{26}$ The eastern church ending- the altar apse (4.40 wide, 2,90 deep.) is very interesting. The wall is from the apse there are several that relate the apse with the side walls. It has pilasters and three protruding contraphors from outside, like the Episcopal basilica in Heraclea and tetra conch in Lychnidos, that seems to have either hold a strong wall with windows and a dome above the apse or to imitate the church in Bethlehem. The building might have had two lateral apses that have not been discovered since the terrain has been plundered many time prior to the archaeological small scope diggings.

The plan of the church, or better the shape of the altar and its walls show this building might has been either an old mausoleum-martyrium or a kind of replica of the Church of the Nativity in Jerusalem, without the five nave part. It is again Palestine model of church that has been built by Constantine and remodeled by Justinian that has been taken as model.

The type of monogram applied usually on Syrian Corinthian capitals of the bishop John from Heraclea (an important figure that also ordered the city fountain and dedicated it to Justinian I), found on an elegant figural composite

\footnotetext{
${ }_{19}$ Mikulčić Ivan, Antički gradovi vo Makedonija, Skopje 1999, 321. Svetozar Radojcic, Crkva u Konjuhu, ZRVII, , Beograd 1952, $148-167$. 20 Viktor Lilcic, Makedonskiot kamen za bogovite, hristijanite i za zivotot posle zivotot, vol.2, Skopje 2002, 832, 834. Mikulcic (I. Mikulčić, Stobi, Skopje 2003, 125) describes the Stobi crypt and ambulatory in details. There was a crypt in the altar part of the church, a semi opened room, 1,5 $\mathrm{m}$ below the floor, shaped as a round segment with a semi-circular wall parallel with the apse at $1 \mathrm{~m}$ distance thus creating a corridor-deambulatorium used by the believers-worshipers to approach the place where the relics of the martyr of Stobi must have been kept. The worshipers could see the relic container, a coffin perhaps, through the intercolumnia, between the 3 columns of the curved wall of the corridor. The floor of the crypt was lowered in order to be closer to the altar of the buried older EB underneath, where the relics must had been initially kept. The crypt was located above the main entrance of the former Roman theater.

${ }^{21}$ Snively says there is also a late literary reference to a similar arrangement in the church of Agia Sophia at Thesalloniki. See Snively, The new basilica at Golemo Gradište, 195.

${ }_{22}$ Bratoz, The Early Christian Church in Macedonia and its relation to Rome, figure on page 37 drown by V.Lilčić.

${ }^{23}$ Blaga Aleksova, Loca Sanctorum Macedoniae, Matica Makedonska Skopje 1995, 380, fig. 105.

${ }^{24}$ Aleksova, Loca Sanctorum, 380.

${ }^{25}$ Caneva Decevska N., Ranohristijanskata arhitektura v Blgaria IV-VI vek, Sofia 1999, 21,84.

${ }^{26}$ Z. Beldedovski, M.Sterjov, Novi soznanija za lokalitetot Kula kaj s. Kalauzlija MAA 19 (309-320).
} 
capital from the small Episcopal church that was used only by the clergy ${ }^{27}$, may indicate that the bishop in question or even the clergy were of Syrian origin.

\section{Analysis Result}

Early Christian architecture on the territory of today's Republic of Macedonia once part of the Roman and Byzantine province Macedonia, shows both usage of fashionable models of single nave churches with square annexes at both sides of the altar or nartex, that might have been the first type of free cross shaped building that has become the usual three nave basilica. Very few models of tetraconchos (Lychnidos), trefoil (St. Clement, St. Naum, Lychnidos) and rotundas (Konjuh) follow the Syrian and Palestine models of mausolea- martiria that has been spread within the whole Empire in the $6^{\text {th }} \mathrm{C}$. To this fashionable buildings and mosaics and furniture that ornate them, we can add some unusual solutionschurch with three baptisteries, two ambos, side entrances to the altar, to the naves, and small exclusive buildings that served as oratorio or private church for the clergy (Heraclea, small Episcopal church). It seems they may be related to some of the religious differences that occurred at the time, or to various liturgy practices that were practiced on the East and the West. Our Episcopal seats were sometimes on good terms with the Pope, sometimes against him, or for and against the new church organizational divisions applied by the Emperor etc. Some churches need much better reexploration at the site and of the documentation of a team of scholars who are very familiar with the theological, architectural and historical aspect related to the archaeological research that has been or is performed by not very well equipped with knowledge local archaeologists.

\section{Referenes}

Aleksova, Blaga(1995), Loca Sanctorum Macedoniae, Matica Makedonska Skopje

Aleksova, Blaga, Lilcic, Viktor (1997). The Early Christian Churches in Macedonia, MH 5

Bitrakova, Vera, Starohristijanski spomenici vo ohridsko, Ohrid 1975, 197. Ibid., Golem Grad Prespa I, Skopje 2011

Bratoz, Rajko (2000). The Early Christian Church in Macedonia and its relation to Rome, MH 13, 3-82.

Cvetanovski, Velimir. (2006) Gradot Stenče, MH 29, 31-46

Caneva Decevska N., Ranohristijanskata arhitektura v Blgaria IV-VI vek, Sofia 1999, 21,84.

Feissel, Denis. (1983) Recueil des inscriptionschretiennes de Macedonine de IIle au Vie siècle, BCH, supl. VIII,

Georgieva, V., Lilčić, V., Filipova K. (2010) The early Christian basilica at Drenovo, MH 34-35, 67-76.

Filipova, Snežana (2010). Early Christian Cultural Centres in Republic of Macedonia along the Via Egnatia, Patrimonium 7-8, 2010, 127148,134 .

Folis, Nadja Kurtović, Milić, Renata (2010) Niš and Byzantium IX, Late Antique centrally planned buildings and their influence on renaissance architecture, 267-282.

Lilcic, Viktor. (2002) Makedonskiot kamen za bogovite, hristijanite i za zivotot posle zivotot, vol.2, Makedonska Civilizacija Skopje

Mango, M.Mundell (2000) Building and architecture, in: The Cambridge Ancient History, vol. XIV, Cambridge, 958-961.

Margalit, Shlomo. The bi-apsidal churches in Palestine, Jordan, Syria, Lebanon and Cyprus. http://www.christusrex.org/www1/ofm/sbf /Books/LA40/LA40321Margalit Bi-apsidal.pdf

Mikulčić, Ivan. (1999). Antički gradovi vo Makedonija, Skopje, 321. Ibid., (2003) Stobi, Skopje

Canak Medic, Milka. (1965). Ispituvanja i rabotite na kozervacijata na mozaikot vo bazilikata A vo Herakleja Linkestis, Heraclea II, 67-74.

Nacev, Trajche, Frkov, Julij(2011). Archaeological architectonic research and reconstruction of an urban early Christian basilica in the city of Bargala, MH 34-35, 157-172

Hristova, Katerina. (2006). Late Medieval Coin Finds from St. Clement's Church of St. Panteleimon in Ohrid, Folia Archaeologica Balkanika I, 485-502,

Oncevska, Marina (2011). The Big Early Christian Basilica in Scupi and Early Christianity, MN 34-35, 97-112, fnote 32.

Radojcic, Svetozar. (1952) Crkva u Konjuhu, ZRVI I, Beograd 1952, 148-167.

Snively, Caroline. (2010). The new basilica at Golemo Gradište, Konjuh: a 6th C. church in the province of Dardania) Nish and Byzantium IX, 187-201198.

Snyder, F. (2003) Ante pacem: archaeological evidence of church life before Constantine, pp. 129-134, Mercer University Press

Beldedovski, Zvonko, Sterjov, Mitko. (2006) Novi soznanija za lokalitetot Kula kaj s. Kalauzlija MAA 19 (309-320).

Teicher, L. "Ancient Eucharistic Prayers in Hebrew (Dura-Europos Parchment D. Pg. 25)", The Jewish Quarterly Review New Series

${ }^{27}$ Milka Canak Medic, Ispituvanja i rabotite na kozervacijata na mozaikot vo bazilikata A vo herakleja Linkestis, Heraclea II, 1965, 67-74.

Denis Feissel, Recueil des inscriptionschretiennes de Macedonine de IIle au Vie siècle, BCH, supl. VIII, 1983, 221. 
54.2 (October 1963), pp. 99-109.

http://www.shadysidelantern.com/if_pulpits_could_talk.htm http://www.ewtn.com/library/liturgy/zlitur246.htm 